\title{
Influence of Fetal Gender on the Concentration of Interleukin-1 Receptor Antagonist in Amniotic Fluid and in Newborn Urine
}

\author{
KRISTINA BRY, URPO LAPPALAINEN, FEIZAL WAFFARN, KARI TERAMO, AND \\ MIKKO HALLMAN \\ Department of Pediatrics, University of California, Irvine, Irvine, California 92717 [K.B., U.L., F.W., M.H.]; and \\ Department of Obstetrics and Gynecology, University of Helsinki, Helsinki, Finland [K.T.]
}

\begin{abstract}
IL-1 receptor antagonist (IL-1 ra) is a cytokine that blocks the effects of IL-1 by binding to IL-1 receptors without inducing signal transduction. Amniotic fluid contains high concentrations of IL-1ra. The purpose of this study was 1) to analyze whether factors related to the mother or the fetus influence amniotic fluid IL-1ra concentration, and 2) to study whether the fetus is a source of IL-1ra. Two hundred two specimens of amniotic fluid, as well as 21 urine samples from newborn infants, were analyzed. Women carrying a female fetus had a higher concentration of amniotic fluid IL-1ra than those carrying a male fetus (female $136.4 \pm 6.1 \mu \mathrm{g} / \mathrm{L}, n=83$; male 74.7 $\pm 3.7 \mu \mathrm{g} / \mathrm{L}, n=119 ; p<0.0001$, unpaired two-sided $t$ test). Length of gestation, presence or absence of labor signs, or elevated IL-1 $\beta$ in amniotic fluid did not affect the concentration of IL-1 ra in amniotic fluid. Urine of infants taken during the first $\mathbf{4 8} \mathrm{h}$ of life contained a high concentration of IL-1ra $(91.1 \pm 17.5 \mu \mathrm{g} / \mathrm{L})$. The urinary IL-1 ra concentration was higher in female newborns than in male newborns (females $124.0 \pm 25.2 \mu \mathrm{g} / \mathrm{L}, n=11$; males 54.9 $\pm 19.1 \mu \mathrm{g} / \mathrm{L}, n=10 ; p=0.04)$. We conclude that 1$)$ the concentration of IL-1 ra in amniotic fluid and newborn urine is dependent on the gender of the fetus and of the newborn and 2) fetal urine is a major source of amniotic fluid IL1ra. The higher IL-1ra in female-bearing gestations may contribute to the better resistance of female fetuses against preterm birth and perinatal infections. (Pediatr Res 35: 130-134, 1994)
\end{abstract}

Abbreviations

IL-1ra, IL-1 receptor antagonist

PROM, premature rupture of the membranes

IL- 1 indicates two structurally related cytokines, IL- $1 \alpha$ and IL- $1 \beta$, that mediate many physiologic responses to infection and inflammation (1). IL- $\alpha$ and IL- $\beta$ act through the same cell surface receptors and share biologic activities (1). IL-1 induces fever, sleep, anorexia, and hypotension (1). It also increases the synthesis of collagenases and prostaglandins, and stimulates the production of several inflammatory mediators (2-5).

IL- 1 ra is a cytokine that is structurally related to IL- $1 \alpha$ and IL-1 $\beta(6)$. IL-1 ra opposes the actions of IL-1 by competing with IL-1 for binding to IL-1 receptors without inducing signal trans-

Received May 24, 1993; accepted August 18, 1993.

Correspondence and reprint requests: Kristina Bry, M.D., University of California, Irvine, Med. Sci. I, Rm C202, Irvine, CA 92717.

Supported by the Foundation for Maternal and Infant Care and the Sigrid Juselius Foundation. duction (6). IL- 1 ra has been shown to block various IL-1-induced responses on many cells (6), including inflammatory changes caused by IL-1 (7). Exogenous administration of IL-1 ra reduces mortality in animal models of sepsis or endotoxemia (8-12).

Preterm labor is strongly associated with intraamniotic infection (13). Bacterial products such as endotoxin stimulate the production of IL-1 by decidual macrophages (14). IL-1 stimulates the production of prostaglandins, major inducers of uterine contractions, by amnion and decidua $(15,16)$. The concentration of this cytokine is elevated in amniotic fluid in women in preterm labor with microbial invasion of the amniotic cavity (17). In addition, administration of IL- 1 to animals induces preterm labor (18). For these reasons, IL-1 has been proposed to act as a mediator in preterm labor occurring in the setting of infection (19). IL-1 ra, on the other hand, inhibits the IL-1-stimulated prostaglandin production by amnion cells $(20,21)$. It also prevents preterm delivery induced in mice by IL-1 (22).

Human amniotic fluid has been reported to contain high IL1 ra concentrations (20). This may be of importance in the defense of the fetoplacental unit against inflammatory conditions mediated by IL-1 (20-22). No patient-related factor is known to affect IL-1 ra concentration in amniotic fluid. The source of amniotic fluid IL-1 ra is likewise unknown. The purpose of this study was 1 ) to analyze whether factors related to the mother or the fetus influence the concentration of IL-1 ra in amniotic fluid, and 2) to study whether the fetus could be a source of IL-1 ra.

\section{SUBJECTS AND METHODS}

Informed consent was obtained from the pregnant patients and the parents of the infants participating in the study. All the amniocenteses were performed for diagnostic purposes.

Amniotic fluid samples. Altogether 202 pregnant women participated in the study; one sample was obtained from each patient. Patient characteristics are shown in Table 1. One hundred thirty-one samples were obtained at a gestational age less than 37 wk. Twenty-nine samples were from women in labor; 173 were from women without signs of labor. Five patients were in preterm labor (i.e. labor at gestational age less than 37 completed wk). One hundred eighty-three samples were obtained transabdominally. Nineteen samples were recovered from the vaginal pool; all of these were from patients in labor at term.

Urine samples. Urine samples of 10 preterm neonates (gestational ages between 27 and $37 \mathrm{wk}$ ) and of 11 term neonates were analyzed for IL-1 ra. All the samples were collected during the first $48 \mathrm{~h}$ of life. The diagnostic categories of the infants were as follows, with the number of patients in each group shown in parentheses: prematurity (gestational age less than $37 \mathrm{wk})(n=$ 4 ), respiratory distress syndrome $(n=4)$, meconium aspiration $(n=5)$, intrauterine asphyxia $(n=4)$, infant of diabetic mother 
Table 1. Characteristics of patients from whom amniotic fluid samples were obtained

\begin{tabular}{|c|c|c|c|}
\hline Diagnosis & $\begin{array}{l}\text { Total number of } \\
\text { pregnant women }\end{array}$ & $\begin{array}{c}\text { Number of women } \\
\text { carrying male/ } \\
\text { female fetus }\end{array}$ & $\begin{array}{l}\text { Gestation } \pm \text { SD } \\
\text { at time when } \\
\text { sample was taken } \\
\text { (d) }\end{array}$ \\
\hline Normal & 49 & $32 / 17$ & $264 \pm 22$ \\
\hline PROM & 17 & $9 / 8$ & $220 \pm 18$ \\
\hline Preeclampsia & 32 & $20 / 12$ & $240 \pm 17$ \\
\hline $\begin{array}{l}\text { Intrahepatic cholestasis } \\
\text { of pregnancy }\end{array}$ & 20 & $14 / 6$ & $253 \pm 6$ \\
\hline Diabetic mother & 25 & $14 / 11$ & $259 \pm 9$ \\
\hline $\mathrm{SGA}^{*}$ & 14 & $5 / 9$ & $249 \pm 11$ \\
\hline Multipara $†$ & 14 & $7 / 7$ & $245 \pm 8$ \\
\hline Miscellaneous $\ddagger$ & 31 & $18 / 13$ & $250 \pm 28$ \\
\hline
\end{tabular}

* SGA, small for gestational age.

† One sample of amniotic fluid was obtained from each pregnant woman.

‡ This category includes the following cases $(n)$ : fetal asphyxia (1), fetal macrosomia (3), fetal chromosomal anomaly (3), maternal hypertension (6), polyhydramnios (3), isoimmunization (8), maternal drug exposure (3), and other maternal disease (4).

$(n=1)$, congenital cytomegalovirus infection $(n=1)$, hydrocephalus $(n=1)$, and congenital anomaly $(n=1)$.

Western blot analysis of IL-1ra protein in amniotic fluid. Proteins were separated by PAGE in the presence of SDS under reducing conditions on a $15 \%$ acrylamide gel and electrotransferred from the gel onto a nitrocellulose membrane, followed by chromogenic detection (Immun-Blot Assay, Bio-Rad, Richmond, CA). A goat anti-human IL-1 ra antibody (R \& D Systems, Minneapolis, MN) was used as the primary antibody. The secondary antibody was rabbit anti-goat IgG alkaline phosphatase conjugate (Sigma, St. Louis, MO). Protein size was estimated by comparison to the $17-\mathrm{kD}$ recombinant human IL-1 ra (R \& D Systems) and to molecular weight standards.

$I L-1$ ra and $I L-I \beta$ assays. IL- 1 ra was quantitated using a commercially available ELISA kit ( $R$ \& D Systems). The sensitivity was set at $650 \mathrm{ng} / \mathrm{L}(38 \mathrm{pmol} / \mathrm{L})$ and the interassay and intraassay coefficients of variation were $8.4 \%$ and $5.9 \%$, respectively. IL- $1 \beta$ measurements were performed by a commercially available kit (Advanced Magnetics, Cambridge, MA). The sensitivity was $4.5 \mathrm{ng} / \mathrm{L}(265 \mathrm{fmol} / \mathrm{L})$ and the interassay and intraassay coefficients of variation were $9.4 \%$ and $9.2 \%$, respectively.

Determination of relative birth weight. Relative birth weight was calculated as follows: (birth weight of infant - mean birth weight of infants of same gestational age and gender)/(SD of birth weight of infants of same gestational age and gender).

Statistical methods. The data are expressed as mean \pm SEM unless otherwise indicated. The Kruskal-Wallis test or regression analysis was used to study association of different variables and IL-1 ra levels. The Mann-Whiney test, with Bonferroni correction, was used for post hoc comparisons of diagnostic groups. To detect differences of means between genders, the unpaired twosided $t$ test was used, with Bonferroni correction, where appropriate.

\section{RESULTS}

Western blot analysis of amniotic fluid IL-Ira. Amniotic fluid was analyzed by Western blot as described in Subjects and Methods. Amniotic fluid IL-1 ra immunoreactivity migrated as one main band around 20 to $22 \mathrm{kD}$, slightly higher than unglycosylated recombinant human IL-1 ra, which migrates around 17 kD (Fig. 1).

IL-Ira concentration in amniotic fluid: dependence on fetal gender. The mean concentration of IL-1 ra in amniotic fluid was $100.0 \pm 3.9 \mu \mathrm{g} / \mathrm{L}(n=202)$ with a range from 5.4 to $330 \mu \mathrm{g} / \mathrm{L}$. In samples taken from women carrying a male fetus, the mean concentration of IL-1 ra was $74.7 \pm 3.7(n=119)$. IL-1 ra concentration was significantly higher [136.4 $\pm 6.1(n=83)]$ in amniotic fluid samples from women carrying a female fetus (Fig.

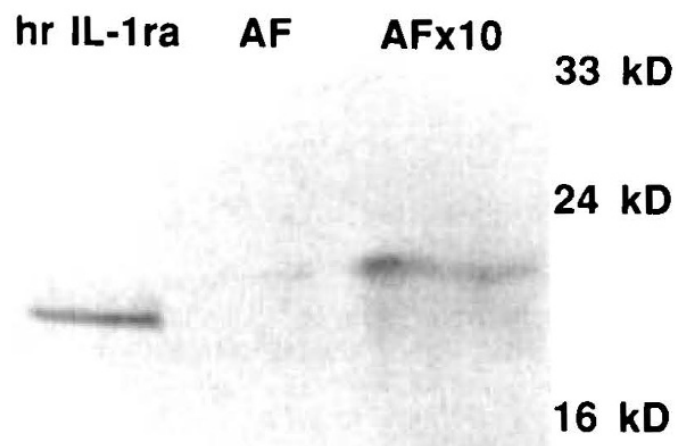

Fig. 1. Western blot of amniotic fluid IL-1 ra. IL-1 ra immunoreactivity in unconcentrated amniotic fluid and in amniotic fluid concentrated 10 -fold is shown. The $17-\mathrm{kD}$ recombinant human IL-1 ra is run in parallel for comparison. On the right-hand side are molecular markers.

$2, p<0.0001$, two-sided unpaired $t$ test). This gender difference was seen at all gestational ages studied (Fig. 2).

Amniotic fluid IL-1 ra was not dependent on gestational age (Fig. 2).

In laboring patients, the concentration of IL-1 ra was $111.8 \pm$ $11.8 \mu \mathrm{g} / \mathrm{L}(n=29)$. In patients not in labor, the concentration was $98.0 \pm 4.2 \mu \mathrm{g} / \mathrm{L}(n=173)$. This difference was not significant.

Using multiple regression analysis (23), we studied the following two factors for their possible association with amniotic fluid IL-1 ra concentration: fetal gender and relative birth weight (Table 2). Of these factors, fetal gender emerged as highly significant $(p<0.0001)$. In addition, relative birth weight was also significantly associated with IL-1 ra $(p=0.03)$.

In laboring patients at term, there was no significant difference in the concentration of IL-1 ra in amniotic fluid between samples taken from the vaginal pool $(130.0 \pm 13.1 \mu \mathrm{g} / \mathrm{L}, n=16)$ and samples taken transabdominally $(100 \pm 21.5 \mu \mathrm{g} / \mathrm{L}, n=8)$.

Amniotic fluid IL-Ira in different diagnostic categories. The concentration of IL-1 ra in amniotic fluid in different patient groups is shown in Figure 3. When both genders were combined, the Kruskal-Wallis test showed a difference between groups ( $p$ $=0.04$ ). In a comparison of pairwise differences, amniotic fluid IL-1 ra in the various groups of pathologic pregnancies did not differ significantly from IL-1 ra in normal pregnancies (Fig. 3, upper panel). However, IL-1 ra tended to be high in patients with twin pregnancies, as well as in mothers of small for gestational age infants.

Within each patient group, amniotic fluid IL-1 ra tended to be higher in female- than in male-bearing gestations (Fig. 3, lower panel). The male-female difference was significant in the follow- 


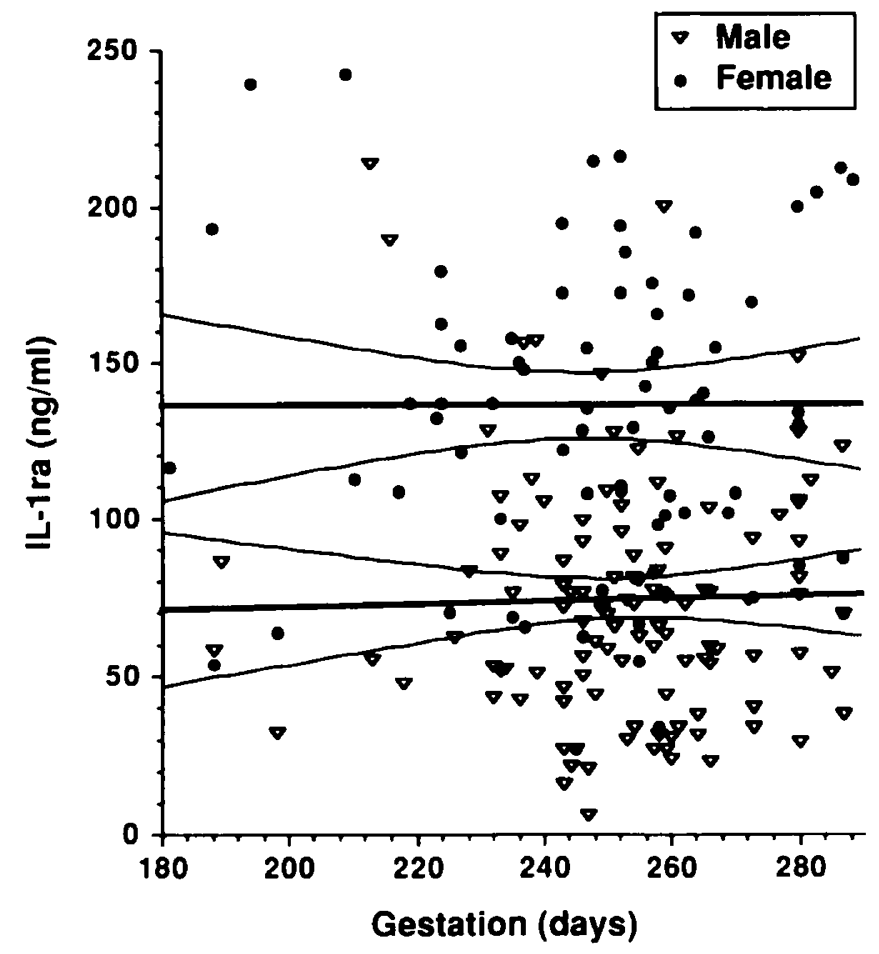

Fig. 2. Amniotic fluid IL-I ra at different gestational ages: dependence on fetal gender. The amniotic fluid concentrations of IL-1 ra in women bearing a male or a female fetus are shown as a function of gestational age. IL-1 ra is expressed in $\mathrm{ng} / \mathrm{mL}$ or $\mu \mathrm{g} / \mathrm{L}(1 \mu \mathrm{g} / \mathrm{L}=59 \mathrm{pmol} / \mathrm{L})$. The regression lines and $90 \%$ confidence bands for means are shown for each gender separately.

ing four patient groups: normal, preterm PROM, maternal diabetes, and miscellaneous (Fig. 3).

Concentration of $I L-1 \beta$ in amniotic fluid. Amniotic fluid IL$1 \beta$ was not associated with fetal gender. As expected (20), it was not associated with amniotic fluid IL-1 ra, either. In patients with PROM at gestational age of less than 34 weeks, amniotic fluid IL- $1 \beta$ concentration was $84.9 \pm 48.7 \mathrm{ng} / \mathrm{L}$ (14), and amniotic fluid IL-1 ra concentration was $133.3 \pm 19.9 \mu \mathrm{g} / \mathrm{L}(n=15)$. In patients without PROM of similar gestational age, IL- $1 \beta$ was above the detection limit only in two (concentrations 9.8 and $4.5 \mathrm{ng} / \mathrm{L}$ ) of a total of 31 specimens ( $p=0.015 \mathrm{vs.} \mathrm{PROM),} \mathrm{but}$ the concentration of IL-1 ra was similar $(108.2 \pm 9.3 \mu \mathrm{g} / \mathrm{L}, n=$ $31, p=0.20$ ) to that in patients with PROM.

Concentration of IL-Ira in urine at birth: gender dependence. All urine samples collected before $48 \mathrm{~h}$ of age from preterm and term neonates contained IL-1 ra. The mean IL-1 ra in newborn urine was $91.1 \pm 17.5(n=21)$, with a range from 5.0 to 297.1 $\mu \mathrm{g} / \mathrm{L}$.

The concentration of IL-1 ra in neonatal urine was higher in female newborns than in male newborns $(p=0.04)$ (Table 3$)$. The gestational ages and birth weights of the female and male neonates were similar.

IL-1 ra in neonatal urine was not dependent on gestational age. The urinary concentration of IL-1 ra was $71.7 \pm 25.6 \mu \mathrm{g} / \mathrm{L}$ (range $5.0-203 \mu \mathrm{g} / \mathrm{L}$ ) in preterm neonates (gestational age less than 37 wk, $n=10$ ) and $108.7 \pm 23.7 \mu \mathrm{g} / \mathrm{L}$ (range 19.7-297 $\mu \mathrm{g} / \mathrm{L}$ ) in term neonates $(n=11)$.

\section{DISCUSSION}

The present results show that women carrying a female fetus have a higher concentration of IL-1 ra in amniotic fluid than women carrying a male fetus. To our knowledge, sex-specific differences in the concentration of IL-1 ra in any body fluids have not previously been reported.

IL-1 ra was present in the urine of newborn infants in very high concentrations, comparable to those in amniotic fluid. An important source of amniotic fluid IL-1 ra is therefore likely to be fetal urine, the major contributor to amniotic fluid volume. Because keratinocytes contain considerable amounts of IL-1 ra (24) and cells from fetal skin are desquamated to amniotic fluid, fetal skin is another possible source of amniotic fluid IL-1 ra. In addition, fetal membrane and decidual cells release IL-1 ra in vitro and may thus also contribute to amniotic fluid IL-1 ra (21, 25).

As a preliminary finding, we report here that IL-1 ra concentration in the urine of female newborns tends to be higher than in male newborns. Most of the infants studied were suffering from severe diseases. A study involving a larger number of patients including normal newborns is needed before any definite conclusion can be drawn regarding the gender dependence of IL1 ra concentration in the urine of newborn infants.

There are limited data available on the concentration of IL1 ra in body fluids, and no reports have been published on the concentration of IL-1 ra in urine or sera of newborns or children. IL-1 ra is present in urine of patients with fever or myelocytic leukemia (26-28). After experimental endotoxemia in human volunteers, IL-1 ra concentrations in plasma increased from 0.46 to $15 \mu \mathrm{g} / \mathrm{L}(29)$. In critically ill patients, plasma IL-1 ra has been reported to range from 0.32 to $55 \mu \mathrm{g} / \mathrm{L}$ (29). IL-1 ra concentration in serum of patients with Hodgkin's disease ranges from 0.63 to $16 \mu \mathrm{g} / \mathrm{L}(30)$. The concentrations found in amniotic fluid or in urine of newborn infants thus greatly exceed those reported previously in the sera or plasma of adults.

IL-1 is a mediator in both local and systemic infections. Furthermore, it has functions in host defense mechanisms, particularly immunologic and hematologic responses (1). It induces fever, decreases blood pressure, lowers systemic vascular resistance, induces neutrophilia, and increases the synthesis of collagenases (1). IL-1 up-regulates the production of other mediators such as platelet-activating factor, prostaglandins, and nitric oxide (5). IL-1 can also induce its own production and that of other cytokines that participate in inflammatory processes $(2-4,31$, 32 ). In addition, the growth of virulent strains of Escherichia coli is enhanced by IL-1 (33).

IL-1 ra alleviates inflammatory effects of IL-1 (7). It inhibits the production of cytokines induced by IL-1 $(34,35)$. In animal models, treatment with IL-1 ra improves survival in Escherichia coli (9), Staphylococcus epidermidis (12), and polymicrobial Gram-negative sepsis (10), as well as in endotoxemia $(8,11)$. IL1 ra is endogenously produced in response to endotoxemia and septic shock (29). Production of IL-l ra can be considered a host defense mechanism to block deleterious effects of IL-1 (5). The balance between the amount of IL-1 and the amount of IL-1 ra may be a critical factor in determining whether the host is able to block the symptoms mediated by IL-1.

Male newborns have increased risks of infection-mediated morbidity and mortality (36-41). Thus, male newborns are two to six times more likely to develop perinatal sepsis or meningitis than female newborns (36-38). The risk of perinatal bacterial infection after PROM is also higher in male than in female

Table 2. Multiple regression analysis of factors potentially affecting concentration of IL-I ra in amniotic fluid

\begin{tabular}{llccc}
\multicolumn{1}{c}{ Factor } & Numerical variable & $\begin{array}{c}\text { Regression } \\
\text { coefficient }\end{array}$ & $\begin{array}{c}\text { Standard } \\
\text { error }\end{array}$ & $p$ \\
\hline Fetal sex & Male $=1$, female $=2$ & 60.9 & 7.2 & $<0.0001$ \\
Relative birth weight & Birth weight in SD of mean & -4.8 & 2.1 & 0.026 \\
\hline
\end{tabular}


Table 3. IL-Ira in newborn urine samples obtained before 48 h of age

\begin{tabular}{lccccc}
\hline & $\begin{array}{c}\text { Both genders } \\
(n=21)\end{array}$ & $\begin{array}{c}\text { Male newborns } \\
(n=10)\end{array}$ & $\begin{array}{c}\text { Female newborns } \\
(n=11)\end{array}$ & $\begin{array}{c}\text { Male vs female } \\
(p)^{*}\end{array}$ & 0.87 \\
Birth weight $(\mathrm{g})$ & $2649 \pm 272$ & $2598 \pm 517$ & $2690 \pm 284$ & 0.26 \\
Gestational age (d) & $251 \pm 7$ & $243 \pm 11$ & $259 \pm 8$ & $124.0 \pm 25.2$ & 0.04 \\
IL-1 ra $(\mu \mathrm{g} / \mathrm{L})$ in urine & $91.1 \pm 17.5$ & $54.0 \pm 19.2$ & & \\
\hline
\end{tabular}

*The two-sided unpaired $t$ test was used to compare males with females.

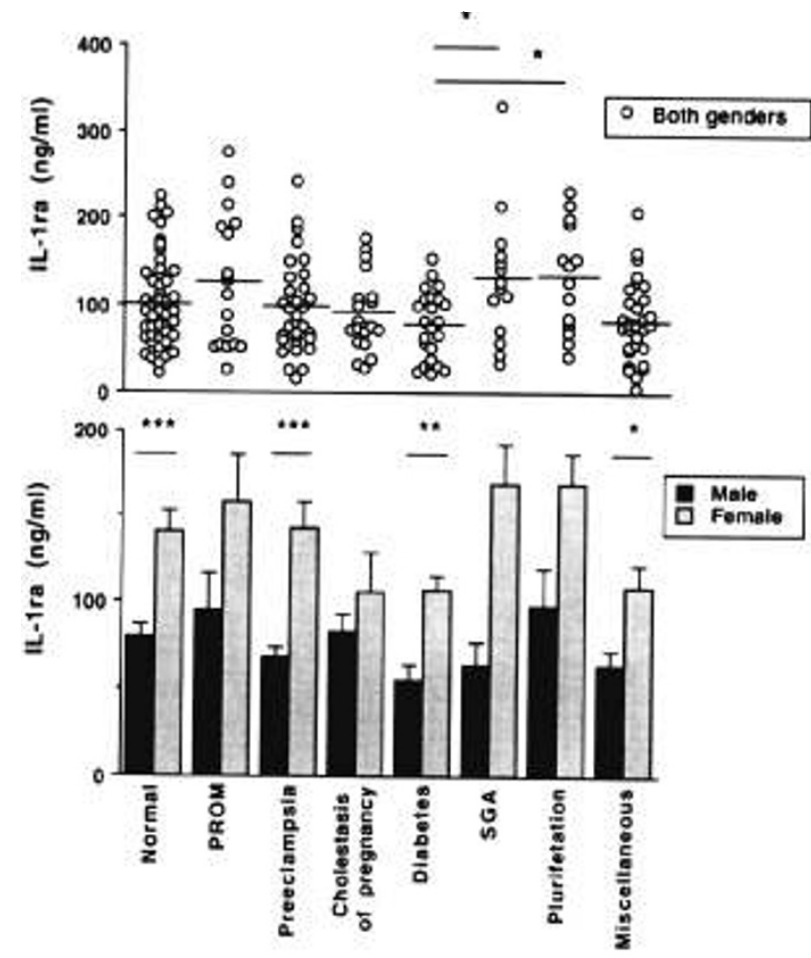

Fig. 3. Amniotic fluid IL-1 ra in different patient categories. The upper panel shows the concentration of IL-1 ra in the indicated patient groups with both genders combined. Horizontal lines show means. Significant differences between pairs of groups are indicated by a horizontal line and star above the data $(p<0.05$, Mann-Whitney test with Bonferroni correction). The lower panel shows the concentrations of IL-1 ra (mean + SEM) separately for male- and female-bearing gestations. IL-1 ra is expressed in $\mathrm{ng} / \mathrm{mL}$ or $\mu \mathrm{g} / \mathrm{L}$. Significant differences (unpaired $t$ test with Bonferroni correction) are indicated as follows: ${ }^{*}, p<0.05 ;{ }^{* *}, p<0.01$; and $* * *, p<0.001$.

neonates (40). Amniotic fluid invaded by microorganisms is an important source of fetal and perinatal infections (42-44). Infection leads to activation of the cytokine network and to increased production of cytokines such as IL-1 (17). IL-1 mediates symptoms and signs of infection. IL-1 ra has been shown to reduce the severity of diseases such as hemodynamic shock and lethal sepsis (8-12). Endogenously produced IL-1 ra may similarly prevent the onset and development of inflammatory lesions. Amniotic fluid IL-1 ra concentration is constitutively high, as shown by present and previous (20) results. Fetal skin is exposed to IL-1 ra present in amniotic fluid. Through swallowing of amniotic fluid and fetal breathing, the gastrointestinal tract and the airways of the fetus are also exposed to IL-1 ra. The increased concentration of IL-1ra in the amniotic fluid surrounding female fetuses and the increased production of IL-1 ra by female fetuses and newborns may contribute to the better resistance to infection of female compared with male fetuses and newborns. However, at present there is no direct evidence indicating that high endogenous IL-1 ra protects against severe infections.

A higher incidence of prematurity in male births than in female births has been documented in several studies (45-48). According to one study, males are more likely than females to be born at
33 to 36 wk of gestation (48). Other studies have found an excess of male births at gestational ages between 24 and 37 wk (45-47). Due to its presence in amniotic fluid in preterm labor occurring in the setting of infection and its stimulatory effects on fetal membrane prostaglandin synthesis, IL- 1 has been proposed to act as a mediator of preterm labor (19). IL-1 ra inhibits the IL-1 induced prostaglandin production by human amnion cells $(20$, 21 ). In mice, preterm delivery induced by IL-1 can be blocked by IL-1 ra (22). A high IL-1 ra in fetal urine and amniotic fluid may inhibit IL-1-induced inflammatory changes in the fetal membranes and in the fetus. The higher IL-1 ra concentration in amniotic fluid surrounding the female fetus and bathing her fetal membranes may be one factor contributing to the lower incidence of infections and preterm deliveries among female fetuses.

The sources of IL-1 ra in the fetus and newborn infant and the regulation of its production remain to be elucidated. The possibility that, in addition to IL-1 ra, other cytokines are gender dependent merits investigation.

\section{REFERENCES}

1. Dinarello CA 1991 Interleukin-1 and interleukin-1 antagonism. Blood $77: 1627-1652$

2. Dinarello CA, Ikejima T, Warner SJ, Orencole SF, Lonnemann G, Cannon JG, Libby $P 1987$ Interleukin 1 induces interleukin 1. I. Induction of circulating interleukin 1 in rabbits in vivo and in human mononuclear cells in vitro. J Immunol 139:1902-1910

3. Ikejima T, Okusawa S, Ghezzi P, van der Meer JWM, Dinarello CA 1990 Interleukin-1 induces tumor necrosis factor (TNF) in human peripheral blood mononuclear cells in vitro and a circulating TNF-like activity in rabbits. J Infect Dis 162:215-223

4. Schindler R, Mancilla J, Endres S, Ghorbani R, Clark SC, Dinarello CA 1990 Correlations and interactions in the production of interleukin-6 (IL-6). IL 1 , and tumor necrosis factor (TNF) in human blood mononuclear cells: IL6 suppresses IL-1 and TNF. Blood 75:40-47

5. Dinarello CA, Wolff SM 1993 The role of interleukin-1 in disease. $N$ Engl $J$ Med 328:106-113

6. Arend WP 1991 Interleukin-1 receptor antagonist. A new member of the interleukin 1 family. J Clin Invest 88:1445-1451

7. Ulich TR, Yin SM, Guo KZ, del Castillo J, Eisenberg SP, Thompson RC 1991 The intratracheal administration of endotoxin and cytokines. III. The inter leukin-1 (IL-1) receptor antagonist inhibits endotoxin- and IL-1-induced acute inflammation. Am J Pathol 138:521-524

8. Ohlsson K, Bjork P, Bergenfeldt M, Hageman R, Thompson RC 1990 Interleukin- 1 receptor antagonist reduces mortality from endotoxin shock. Nature 348:550-555

9. Wakabayashi G, Gelfand JA, Burke JF, Thompson RC. Dinarello CA 1991 A specific receptor antagonist for interleukin 1 prevents Escherichia coliinduced shock in rabbits. FASEB J 5:338-343

10. Alexander HR, Doherty GM, Venzon DJ, Merino MJ, Fraker DL, Norton JA 1992 Recombinant interleukin-1 receptor antagonist (IL-1 ra): effective therapy against gram-negative sepsis in rats. Surgery 112:188-193

11. Alexander HR, Doherty GM, Buresh CM, Venzon DJ, Norton JA 1991 A recombinant human receptor antagonist to interleukin 1 improves survival after lethal endotoxemia in mice. J Exp Med 173:1029-1032

12. Fischer E, Marano MA, van Zee KJ, Rock CS, Hawes AS, Thompson WA, DeForge L, Kenney JS, Remick DG, Bloedow DC 1992 Interleukin-1 receptor blockade improves survival and hemodynamic performance in Escherichia coli septic shock, but fails to alter host responses to sublethal endotoxemia. J Clin Invest 89:1551-1557

13. Gibbs RS, Romero R, Hillier SL, Eschenbach DA, Sweet RL 1992 A review of premature birth and subclinical infection. Am J Obstet Gynecol 166:15151528

14. Romero R, Wu YK, Brody DT, Oyarzun E, Duff GW, Durum SK. 1989 Human decidua: a source of interleukin-1. Obstet Gynecol 73:31-34

15. Romero R, Durum S, Dinarrello CA, Oyarzun E, Hobbins JC, Mitchell MD 1989 Interleukin-1 stimulates prostaglandin biosynthesis by human amnion. Prostaglandins 37:13-22

16. Mitchell MD, Edwin S, Romero R 1990 Prostaglandin biosynthesis by human decidual cells: effects of inflammatory mediators. Prostaglandins Leukot Essent Fatty Acids 41:35-38

17. Romero R, Mazor M, Brandt F, Sepulveda W, Avila C, Cotton DB, Dinarello 
CA 1992 Interleukin-1 alpha and interleukin-1 beta in preterm and term human parturition. Am J Reprod Immunol 27:117-123

18. Romero R, Mazor M, Tartakovsky B 1991 Systemic administration of interleukin-1 induces preterm parturition in mice. Am J Obstet Gynecol 165:969971

19. Romero R, Brody DT, Oyarzun E, Mazor M, Wu YK, Hobbins JC, Durum SK 1989 Infection and labor. III. Interleukin-1: a signal for the onset of parturition. Am J Obstet Gynecol 160:1117-1123

20. Romero $R$, Sepulveda W, Mazor M, Brandt F, Cotton DB, Dinarello CA, Mitchell MD 1992 The natural interleukin-1 receptor antagonist in term and preterm parturition. Am J Obstet Gynecol 167:863-872

21. Bry K, Lappalainen U, Hallman M 1993 Interleukin-1 binding and prostaglandin $E_{2}$ synthesis by amnion cells in culture: regulation by tumor necrosis factor- $\alpha$, transforming growth factor- $\beta$, and interleukin- 1 receptor antagonist. Biochim Biophys Acta 1181:31-36

22. Romero R, Mazor M, Tartakovsky B 1992 The natural interleukin-1 receptor antagonist prevents interleukin-1-induced preterm parturition. Am J Obstet Gynecol 167:1041-1045

23. Pocock SJ 1983 Clinical Trials. A Practical Approach. Wiley, New York, pp 212-214

24. Haskill S, Martin G, Van Le L, Morris J, Peace A, Bigler CF, Jaffe GJ, Hammerberg C, Sporn SA, Fong S, Arend WP, Ralph P 1991 cDNA cloning of an intracellular form of the human interleukin 1 receptor antagonist associated with epithelium. Proc Natl Acad Sci USA 88:3681-3685

25. Bry K, Hallman M 1993 Transforming growth factor- $\beta 1$ potentiates the stimulatory effect of interleukin-4 on the production of interleukin-1 receptor antagonist by decidual cells. J Cell Biochem 17B:102(abstr)

26. Liao Z, Grimshaw RS, Rosentreich DL 1984 Identification of a specific interleukin-1 inhibitor in the urine of febrile patients. J Exp Med 159:125136

27. Balavoine JF, de Rochemonteix B, Williamson K, Seckinger $P$, Cruchaud A, Dayer JM 1986 Prostaglandin $E_{2}$ and collagenase production by fibroblasts and synovial cells is regulated by urine-derived human interleukin 1 and inhibitor(s). J Clin Invest 78:1120-1124

28. Seckinger $P$ Lowenthal JW, Williamson K, Dayer JM, MacDonald HR 1987 A urine inhibitor of interleukin-1 activity that blocks ligand binding. $J$ Immunol 139:1546-1549

29. Fischer E, Van Zee KJ, Marano MA, Rock CS, Kenney JS, Poutsiaka DD, Dinarello CA, Lowry SF, Moldawer LL 1992 Interleukin-1 receptor antagonist circulates in experimental inflammation and in human disease. Blood 79:2196-2200

30. Gruss HJ, Dolken G, Brach MA, Mertelsmann R, Herrmann F 1992 High concentrations of the interleukin-1 receptor antagonist in serum of patients with Hodgkin's disease. Lancet 2:968
31. Guerne PA, Carson DA, Lotz M 1990 IL-6 production by human articular chondrocytes. Modulation of its synthesis by cytokines, growth factors, and hormones in vitro. J Immunol 144:499-505

32. Schmouder RL, Strieter RM, Wiggins RC, Chensue SW, Kunkel SL 1992 In vitro and in vivo interleukin-8 production in human renal cortical epithelia. Kidney Int 41:191-198

33. Porat R, Clark BD, Wolff SM, Dinarello CA 1991 Enhancement of growth of virulent strains of Escherichia coli by interleukin-1. Science $254: 430-432$

34. DeForge LE, Tracey DE, Kenney JS, Remick DG 1992 Interleukin-1 receptor antagonist protein inhibits interleukin-8 expression in lipopolysaccharidestimulated human whole blood. Am J Pathol 140:1045-1054

35. Granowitz EV, Vannier E, Poutsiaka DD, Dinarello CA 1992 Effect of interleukin-1 (IL-1) blockade on cytokine synthesis: II. IL-1 receptor antagonist inhibits lipopolysaccharide-induced cytokine synthesis by human monocytes. Blood 79:2364-2369

36. Durham EC 1933 Septicemia in the newborn. Am J Dis Child 45:229-253

37. Smith RT, Platou ES, Good RA 1956 Septicemia of the newborn: current status of the problem. Pediatrics 17:549-575

38. Washburn TC, Medearis DN Jr, Childs B 1965 Sex differences in susceptibility to infections. Pediatrics 35:57-64

39. Klein JO, Marcy SM 1976 Bacterial sepsis and meningitis. In: Remington JS Klein JO (eds) Infectious Diseases of the Fetus and Newborn Infant. WB Saunders, Philadelphia, pp 679-734

40. St. Geme JW, Murray DL, Carter JA, Hobel CJ, Leake RD, Anthony BF, Thibeault DC, Ross IB, Drage JS 1984 Perinatal bacterial infection after prolonged rupture of amniotic membranes: an analysis of risk and management. J Pediatr 104:608-613

41. Modlin JF 1986 Perinatal echovirus infection: insights from a literature review of 61 cases of serious infections and 16 outbreaks in nurseries. Rev Infect Dis 8:918-926

42. Jason JM 1989 Infectious disease-related deaths of low birth weight infants, United States, 1968 to 1982 . Pediatrics 84:296-303

43. Gibbs RS, Duff P 1991 Progress in pathogenesis and management of clinical intraamniotic infection. Am J Obstet Gynecol 164:1317-1326

44. Seo K, McGregor JA, Frech JI 1992 Preterm birth is associated with increased risk of maternal and neonatal infection. Obstet Gynecol 79:75-80

45. Hall MH, Carr-Hill R 1982 Impact of sex ratio on onset and management of labour. Br Med J 285:401-403

46. MacGillivray I, Davey DA 1985 The influence of fetal sex on rupture of the membranes and preterm labor. [letter] Am J Obstet Gynecol 153:814-815

47. Seki K, Kato K 1987 Increased boy-to-girl ratio in women with preterm labor beginning with contractions. [letter] Am J Obstet Gynecol 157:215-216

48. McGregor JA, Leff M, Orleans M, Baron A 1992 Fetal gender differences in preterm birth: finding in a North American cohort. Am J Perinatol 9:43-48 